Article

\title{
Modifying the acidity of H-MOR and its catalytic carbonylation of dimethyl ether
}

\author{
Meixia Wang, Shouying Huang *, Jing Lü, Zaizhe Cheng, Ying Li, Shengping Wang, Xinbin Ma\# \\ Key Laboratory for Green Chemical Technology of Ministry of Education, School of Chemical Engineering and Technology, Tianjin University; \\ Collaborative Innovation Center of Chemical Science and Engineering (Tianjin), Tianjin 300072, China
}

\section{A R T I C L E I N F O}

\section{Article history:}

Received 13 April 2016

Accepted 30 May 2016

Published 5 September 2016

\section{Keywords:}

Zeolite

H-mordenite

Modification of acidity

Hydrothermal synthesis

Structure-direct agent

Post treatment

Carbonylation of dimethyl ether

\begin{abstract}
A B S T R A C T
Among the reactions catalyzed by zeolites there are some that exhibit high selectivity due to the spatial confinement effect of the zeolite framework. Tailoring the acidity, particularly the distribution and location of the Brönsted acid sites in the zeolite is effective for making it a better catalyst for these reactions. We prepared a series of H-mordenite (H-MOR) samples by varying the composition of the sol-gel, using different structure directing agents and post-treatment. $\mathrm{NH}_{3}-\mathrm{TPD}$ and IR characterization of adsorbed pyridine were employed to determine the amount of Brönsted acid sites in the 8-membered ring and 12-membered ring channels. It was shown that controlled synthesis was a promising approach to improve the concentration of Brönsted acid sites in MOR, even with a low $\mathrm{Al}$ content. Using an appropriate composition of $\mathrm{Si}$ and $\mathrm{Al}$ in the sol-gel favored a higher proportion of Brönsted acid sites in the 8-membered ring channels. HMI as a structure-direct agent gave an obvious enrichment of Brönsted acid sites in the 8-membered ring. Carbonylation of dimethyl ether was used as a probe reaction to examine the modification of the acid properties, especially the Brönsted acid sites in the 8-membered ring channels. There was a linear relationship between methyl acetate formation and the number of Brönsted acid sites in the 8-membered ring channels, demonstrating the successful modification of acid properties. Our results provide information for the rational design and modification of zeolites with spatial constraints.
\end{abstract}

(C) 2016, Dalian Institute of Chemical Physics, Chinese Academy of Sciences. Published by Elsevier B.V. All rights reserved.

\section{Introduction}

Zeolites have been extensively applied as solid acid catalysts in a variety of petrochemical processes and chemical synthesis due to their unique acidity and well-defined microporous framework [1,2]. In aluminosilicate zeolites, the Brönsted acid sites which function as active centers are the protons that balance the negative charge of the tetrahedrally coordinated aluminum (Al) atoms in the framework [3]. It has been generally accepted that the strength and amount of acid sites are key parameters that influence the catalytic performance for many reactions. On the other hand, the pore structure plays an important role not only in diffusion limitation but also in the reaction mechanism. In addition, the siting and distribution of the framework $\mathrm{Al}$ atoms with the concurrent changes in the distribution of Brönsted acid sites have been recognized to influence the catalytic activity and selectivity. Because it offers varying steric access to reactant molecules, spatial constraints for the

\footnotetext{
* Corresponding author. Tel: +86-22-27409880; Fax: +86-22-87401818; E-mail: huangsy@tju.edu.cn

\# Corresponding author. Tel: +86-22-27409880; Fax: +86-22-87401818; E-mail: xbma@tju.edu.cn

This work was supported by the National Natural Science Foundation of China $(21325626,21406120)$ and the Postdoctoral Science Foundation of China (2014M560181, 2015T80214).

DOI: 10.1016/S1872-2067(16)62484-1 | http://www.sciencedirect.com/science/journal/18722067 | Chin. J. Catal., Vol. 37, No. 9, September 2016
} 
reaction intermediates or transition states as well as subtle differences in acid strength are due to the bond angles of the tetrahedral [4]. To date, many works have explored the relationship between the catalytic properties and Al distribution in zeolites. For example, Bell and his coworkers [5] controlled the fraction of $\mathrm{Al}$ in the intersections of H-MFI by varying the $\mathrm{Al}$ content of the zeolite framework and found that terminal cracking and dehydrogenation of $n$-butane happened preferentially on the Brönsted acid sites located at channel intersections. Davis's group [6] demonstrated that the location of acid sites can be tailored by using differently sized cyclic amines as the structure directing agent (SDA), which influenced the performance of carbonylation of dimethyl ether (DME). Pinar et al. [7] discovered that the accessibility of the acid sites determined by the Al position had a good correlation with the catalytic results of $m$-xylene and 1-butene isomerisation. There are several strategies to modify the distribution and local environment of the Al atoms: choosing an appropriate SDA and synthesis conditions, controlling the composition of the reaction mixtures, and adopting post-treatment (including acidic or alkaline leaching, other chemical treatment, steam or thermal treatment, etc.) [8].

The carbonylation of DME to methyl acetate (MA) over zeolites is a typical spatially confined reaction. Iglesia and his colleagues [9] compared different types of zeolites (e.g. FER, MOR, ZSM-5, USY) and found that H-MOR exhibited excellent selectivity (>99\%) to MA. The reaction proceeded as follows: DME reacted with Brönsted acid sites to form $-\mathrm{CH}_{3}$, acetyl formation by $\mathrm{CO}$ insertion into $-\mathrm{CH}_{3}$, then, the acetyl reacted with another DME molecule to produce MA. A further study revealed that the stabilization of the carbocationic transition states (produced by CO insertion into $-\mathrm{CH}_{3}$ ) resulted in the specificity of the 8-membered ring (8-MR) channels in H-MOR [10]. An investigation by quantum chemical methods suggested that the T3-033 position was selective not only due to the channel size but also the unusual orientation of $-\mathrm{OCH}_{3}$ [11]. Shen's group [12] discovered that H-ZSM-35 with a 10-MR channel intersected perpendicularly by an 8-MR channel showed a similarly high initial selectivity to MA and much better stability. Recently, carbonylation of DME has attracted much attention for its atom economy, mild reaction conditions and inexpensive catalysts. More important, it is an important step in the direct route of ethanol production from syngas [13]. Therefore, regulating the distribution of the $\mathrm{Al}$ atoms in a zeolitic framework and elucidating its impact on the catalytic activity would help to understand the structure-function mechanism of zeolites and facilitate ethanol production and syngas utilization.

In previously published works, chemical dealumination and cation-exchange were employed to explore the confinement effect of MOR for DME carbonylation. Both of these were based on the reduction of Brönsted acid sites [14,15]. Here, we regulated the distribution of $\mathrm{Al}$ atoms in the MOR framework in both positive and negative ways, such as controlling the composition of the sol-gel, using different SDAs and using an acidic post-treatment. Ammonia temperature-programmed desorption ( $\mathrm{NH}_{3}-\mathrm{TPD}$ ) and in situ Fourier transform infrared (FTIR) were applied to characterize the acid properties of the H-MOR samples. Due to the increased number of Brönsted acid sites, the carbonylation of DME was facilitated. The relationship between the Brönsted acid sites in the 8-MR channel of H-MOR and the MA formation rate revealed that we achieved a controllable modification of the acid properties in MOR.

\section{Experimental}

\subsection{Preparation of MOR zeolite}

\subsubsection{Hydrothermal synthesis}

MOR zeolite with different $\mathrm{Si} / \mathrm{Al}$ ratios was prepared by hydrothermal synthesis. First, sodium hydroxide, silica sol (30 wt $\% \mathrm{SiO}_{2}, 70 \mathrm{wt} \% \mathrm{H}_{2} \mathrm{O}$ ) and sodium aluminate were mixed and stirred at ambient temperature for $4 \mathrm{~h}$. Then, commercial MOR (Yangzhou Zhonghe Petroleum Chemicals Institute Co., Ltd.) as seed ( $1 \mathrm{wt} \%$ relative to $\mathrm{SiO}_{2}$ ) and tetraethylammonium hydroxide solution (TEAOH, 25 wt\%, Guangfu Fine Chemical Co., Ltd.) as SDA were added to the Si-Al-Na mixture and stirred for $1 \mathrm{~h}$. The reaction gel had the following molar composition: 1.0 $\mathrm{SiO}_{2}: x \mathrm{NaAlO}_{2}: 0.2 \mathrm{NaOH}: 0.23 \mathrm{TEAOH}(x=0.1,0.083,0.067$, 0.056 , corresponding to $\mathrm{Si} / \mathrm{Al}$ ratio $=10,12,15,18)$. The mixture was transferred into a Teflon-lined $100 \mathrm{~mL}$ autoclave and heated at $443 \mathrm{~K}$ for $3 \mathrm{~d}$ under static condition and autogenous pressure. After the autoclave was cooled down, the solid was recovered by filtration and washed with distilled water and dried in an oven at $373 \mathrm{~K}$ for $12 \mathrm{~h}$. The solid was calcined at 823 $\mathrm{K}$ for $5 \mathrm{~h}$ with a heating rate of $1 \mathrm{~K} / \mathrm{min}$ to remove organic compounds. In order to get H-MOR, the calcined Na-MOR zeolite was dispersed in $\mathrm{NH}_{4} \mathrm{NO}_{3}$ aqueous solution $(0.2 \mathrm{~mol} / \mathrm{L}, 1 \mathrm{~g}$ sample in $50 \mathrm{~mL}$ solution) at $353 \mathrm{~K}$ for $6 \mathrm{~h}$, followed by filtering and washing. After repeating the ion exchange once, the resulting solid was dried at $373 \mathrm{~K}$ overnight and then calcined at 773 $\mathrm{K}$ for $4 \mathrm{~h}$ with a heating rate of $2 \mathrm{~K} / \mathrm{min}$. When $x=0.083$ in the composition, the Na-MOR was labeled as NaM. The H-MOR samples were labeled as HM1, HM2, HM3 and HM4 with decreasing $x$ values.

When using hexamethyleneimine (HMI 99 wt\%, Sigma-Aldrich Co. LLC.) as the SDA, the synthesis procedure was almost the same. Extra distilled water was needed to dilute HMI. The molar ratio of $\mathrm{H}_{2} \mathrm{O} / \mathrm{SiO}_{2}$ was 13.3 in accordance with the gel using TEAOH as template. The composition of the final mixture was $1.0 \mathrm{SiO}_{2}: 0.083 \mathrm{NaAlO}_{2}: 0.2 \mathrm{NaOH}: 0.35 \mathrm{HMI}$ [16]. The H-MOR obtained was marked as HM5.

\subsubsection{Post-treatment by acid}

The commercial H-MOR (labeled as HM) was used as a parent sample. Acid treatment was applied to regulate the content and distribution of the $\mathrm{Al}$ atoms in HM. Post-treatment with citric acid was carried out at $353 \mathrm{~K}$ under refluxing for $24 \mathrm{~h}(1 \mathrm{~g}$ zeolite in $20 \mathrm{~mL}$ solution). The sample was then filtered off and washed with distilled water until the $\mathrm{pH}=7$ and calcined at 823 $\mathrm{K}$ for $4 \mathrm{~h}$. The samples treated with citric acid were labeled as $\mathrm{C} 1$ and $\mathrm{C} 2$ for the concentration of the solution with 0.2 and 0.5 mol/L, respectively. The parent sample was treated with phosphoric acid as follows: incipient impregnation with phosphoric acid ( $0.15 \mathrm{~mol} / \mathrm{L})$ at room temperature overnight, then 
drying the solid product at $373 \mathrm{~K}$ and calcining at $823 \mathrm{~K}$ for $4 \mathrm{~h}$. The resulting sample was labeled as $\mathrm{P}$.

\subsection{Characterization}

X-ray diffraction (XRD) patterns of the zeolite samples were recorded by a Rigaku D/max-2500 diffractometer with $\mathrm{Cu} K_{\alpha}$ radiation $(\lambda=0.154056 \mathrm{~nm}, 40 \mathrm{kV}$ and $200 \mathrm{~mA})$ in the $2 \theta$ range of $3^{\circ}-50^{\circ}$.

Elemental analysis of $\mathrm{Na}, \mathrm{Al}$, and $\mathrm{Si}$ in the samples was performed on an ICP-OES (VISTA-MPX, Varian). The sample (20 $\mathrm{mg}$ ) was digested in $\mathrm{HF}$ aqueous solution, followed by the addition of excess boric acid $\left(\mathrm{H}_{3} \mathrm{BO}_{3}\right)$ to form a complex with HF.

A Micromeritics ASAP-2020 analyzer was employed to get detailed information about the pore distribution and specific surface area of the samples. Nitrogen adsorption was carried out at $77 \mathrm{~K}$. Prior to the analysis, the sample was degassed at $473 \mathrm{~K}$ for $24 \mathrm{~h}$. The pore volume was calculated by the HorvathKawazoe equation. The surface area was obtained by the Brunauer-Emmett-Teller (BET) method. The micropore volume and the external surface area were obtained from the $t$-plot method.

$\mathrm{NH}_{3}$-TPD was performed on a Micromeritics Autochem II 2920 instrument equipped with a thermal conductivity detector (TCD). The 40-60 mesh catalyst (10 mg) was placed in a quartz tube. In each experiment, the sample was pre-treated at $473 \mathrm{~K}$ for $1 \mathrm{~h}$ and cooled down to $423 \mathrm{~K}$ under Ar flow. After exposure to excess $\mathrm{NH}_{3}$, the sample was purged by Ar flow (30 $\mathrm{mL} / \mathrm{min}$ ) for $1 \mathrm{~h}$ to remove physically adsorbed $\mathrm{NH}_{3}$. Then, the sample was heated from 373 to $1000 \mathrm{~K}(10 \mathrm{~K} / \mathrm{min})$. The released $\mathrm{NH}_{3}$ was detected by a TCD.

FTIR spectra were recorded on a Thermo Scientific Nicolet 6700 connected to an evacuation system. Pyridine was applied as a probe molecule to determine the concentration of Brönsted acid sites in the 12-MR channels of H-MOR. The catalyst (16 $\mathrm{mg}$ ) was pressed into a $13 \mathrm{~mm}$ self-supported wafer and loaded into an in situ cell with $\mathrm{CaF}_{2}$ windows. Subsequently, the sample was pre-treated at $723 \mathrm{~K}$ for $30 \mathrm{~min}$ under vacuum. When the wafer had cooled down and stabilized at $423 \mathrm{~K}$, the background spectrum was recorded. After saturation by pyridine vapor for $30 \mathrm{~min}$, the sample was evacuated for 30 min to remove physically adsorbed pyridine. All spectra were collected in the range of $650-4000 \mathrm{~cm}^{-1}$ by averaging 32 scans at a resolution of $4 \mathrm{~cm}^{-1}$. The concentration of Brönsted acid sites $\left(1540 \mathrm{~cm}^{-1}\right)$ was calculated according to Ref. [17].

\subsection{Catalytic performance}

Carbonylation of DME to MA was evaluated in a fixed-bed stainless steel reactor at $1.5 \mathrm{MPa}$. In a typical run, $1 \mathrm{~mL}$ of catalyst (0.5 g, 40-60 mesh) was placed in the reactor. Prior to the reaction, the catalyst was pre-treated in $\mathrm{N}_{2}$ atmosphere (99.99\%, Tianjin Sixon Gas Co., Ltd) at $473 \mathrm{~K}$ for $9 \mathrm{~h}$. The reactant mixture (DME/CO = 1/49, $\mathrm{mol} / \mathrm{mol}$ ) was introduced into the reactor at a total flow rate of $100 \mathrm{~mL} / \mathrm{min}$. The product gas was analyzed by an online gas chromatograph (Agilent 7890B GC) which was equipped with both flame ionization detector (FID) and TCD. The selectivity and space time yield (STY) of MA were calculated by Eqs. (1) and (2), respectively.

$$
\begin{gathered}
S_{\mathrm{MA}}=\mathrm{MA} /\left(\mathrm{CH}_{3} \mathrm{OH} / 2+\mathrm{MA}+\mathrm{CH}_{3} \mathrm{COOH}\right) \\
\mathrm{STY}_{\mathrm{MA}}=X_{\mathrm{DME}} \times S_{\mathrm{MA}}
\end{gathered}
$$

Due to coke formation, the conversion of DME on all the H-MOR samples decreased gradually and rapidly with time on stream. Therefore, the initial catalytic performance (reaction time $1.5 \mathrm{~h}$ ) was discussed in this work.

\section{Results and discussion}

\subsection{Composition analysis and textural properties}

ICP-OES was applied for element analysis. The molar ratios of silicon and aluminum in the different samples are displayed in Table 1. They varied within a small range from 7.9 to 11.8. For the synthesized sample, we noticed that the $\mathrm{Si} / \mathrm{Al}$ ratios in the samples were much less than the composition of the raw materials in the mixed sol-gel, indicating a loss of silica in the hydrothermal synthesis. With increasing Si/Al ratio in the sol-gel, the gap continued to widen. Generally, most of the direct synthesis methods of MOR yielded a product with a $\mathrm{Si} / \mathrm{Al}$ ratio of 10 unless some special SDA or fluoride addition was employed [18,19]. Compared with HM1-HM4, HM5 had a higher content of silicon, which was very close to the value in the synthesis mixture. This suggested that HMI as a template favored the formation of high silica MOR zeolite in comparison to TEAOH [18]. On the other hand, it was also reported that more amorphous silicon species were deposited on the nuclei because of the weak structure-directing ability of HMI [20]. Post-treatment with chemicals is considered a simple and practical strategy to adjust the composition of the zeolite framework. As shown in Table 1 , the $\mathrm{Si} / \mathrm{Al}$ ratio of commercial H-MOR increased after the treatment with citric acid and

Table 1

\begin{tabular}{|c|c|c|c|c|c|c|c|c|}
\hline \multirow{2}{*}{ Sample } & \multirow{2}{*}{$\mathrm{Si} / \mathrm{Al}$} & \multirow{2}{*}{$\begin{array}{c}\text { Relative crystallinity } \\
(\%)\end{array}$} & \multicolumn{3}{|c|}{ Surface area $\left(\mathrm{m}^{2} / \mathrm{g}\right)$} & \multicolumn{3}{|c|}{ Pore volume $\left(\mathrm{cm}^{3} / \mathrm{g}\right)$} \\
\hline & & & BET & Micropore & External & Total & Micropore & Mesopore \\
\hline HM1 & 8.2 & 104 & 423.6 & 414.6 & 9.0 & 0.194 & 0.193 & 0.001 \\
\hline HM2 & 10.2 & 103 & 464.8 & 436.2 & 28.6 & 0.220 & 0.203 & 0.017 \\
\hline HM3 & 11.1 & 103 & 445.3 & 402.0 & 43.3 & 0.220 & 0.187 & 0.033 \\
\hline HM4 & 11.8 & 100 & 459.0 & 449.1 & 9.9 & 0.209 & 0.209 & 0 \\
\hline HM5 & 11.8 & 93 & 389.5 & 378.3 & 11.2 & 0.196 & 0.176 & 0.020 \\
\hline $\mathrm{HM}$ & 8.2 & 100 & 447.5 & 422.1 & 25.4 & 0.246 & 0.197 & 0.049 \\
\hline $\mathrm{C} 1$ & 9.3 & 93 & 480.5 & 407.1 & 73.4 & 0.291 & 0.190 & 0.101 \\
\hline $\mathrm{C} 2$ & 10.8 & 88 & 437.5 & 371.6 & 65.9 & 0.276 & 0.177 & 0.099 \\
\hline$\underline{P}$ & 8.5 & 98 & 463.3 & 404.7 & 58.6 & 0.268 & 0.188 & 0.080 \\
\hline
\end{tabular}

Composition analysis and textural properties of the H-MOR samples. 
phosphoric acid, which was consistent with other published works [21,22]. Furthermore, when a higher concentration of citric acid solution was used, a more severe dealumination was observed.

XRD was applied to monitor the structure and crystallinity of the MOR samples. As depicted in Fig. 1, all samples showed the characteristic peaks of zeolite MOR (PDF 43-0171) without any other crystal phase [23]. The relative crystallinity was calculated by comparing the total areas of five peaks with the commercial sample HM (relative crystallinity, 100\%). The position of these peaks were $2 \theta=9.8^{\circ}, 19.6^{\circ}, 22.3^{\circ}, 25.7^{\circ}$, and $26.3^{\circ}$, which corresponded to the crystal planes of (200), (330), (150), (202), and (350). As summarized in Table 1, this indicated that all the samples that use different synthesis mixture compositions exhibited similar crystallinity. The sample directed by HMI had a lower crystallinity. Compared to TEAOH, HMI possessed weaker alkalinity. As a weak SDA, HMI could not effectively induce nucleation, which resulted in a lower nucleation rate and more amorphous silicon species. A similar phenomenon was reported by Wu et al. [20] in TS-1 synthesis. Post-treatment by citric acid and phosphoric acid led to a slight loss of the crystal architecture. In addition, the crystallinity decreased with increasing acid concentration, implying the removal of framework T-atoms.

Nitrogen adsorption at liquid nitrogen temperature was carried out to characterize the textural properties of the samples. Figure 2 presents the adsorption isotherms. According to the IUPAC classification, the samples prepared by hydrothermal synthesis (HM1-HM5) exhibited Type I isotherms, which demonstrated their microporous structure. The commercial and acid-treated samples showed a combination of Type I and IV isotherms with hysteresis loops, suggesting the existence of both micro- and mesopores. The calculated specific surface areas and pore volumes are listed in Table 1. For H-MOR samples with TEAOH as the template (HM1-HM4), the surface areas were similar in the range from 423 to $459 \mathrm{~m}^{2} / \mathrm{g}$. The pore

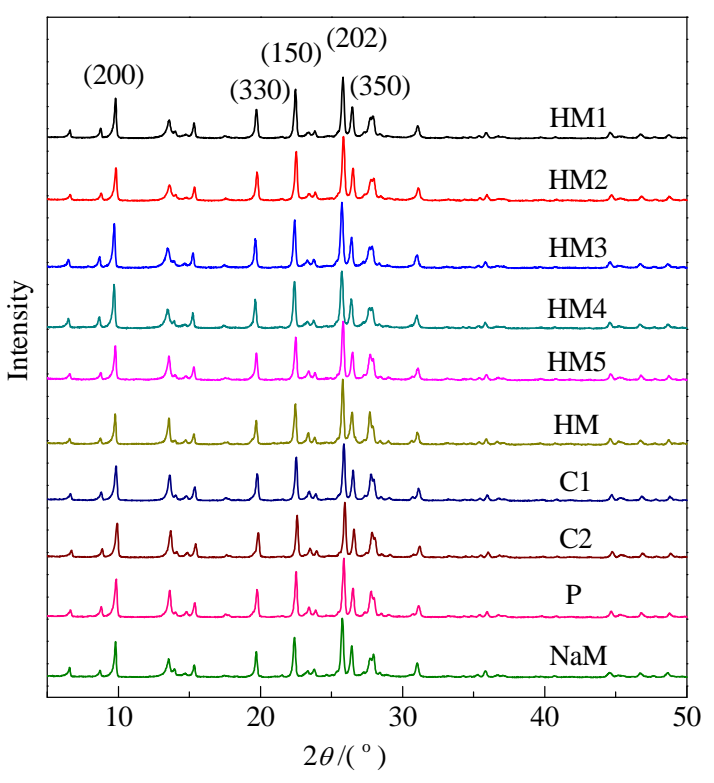

Fig. 1. XRD patterns of the MOR samples.

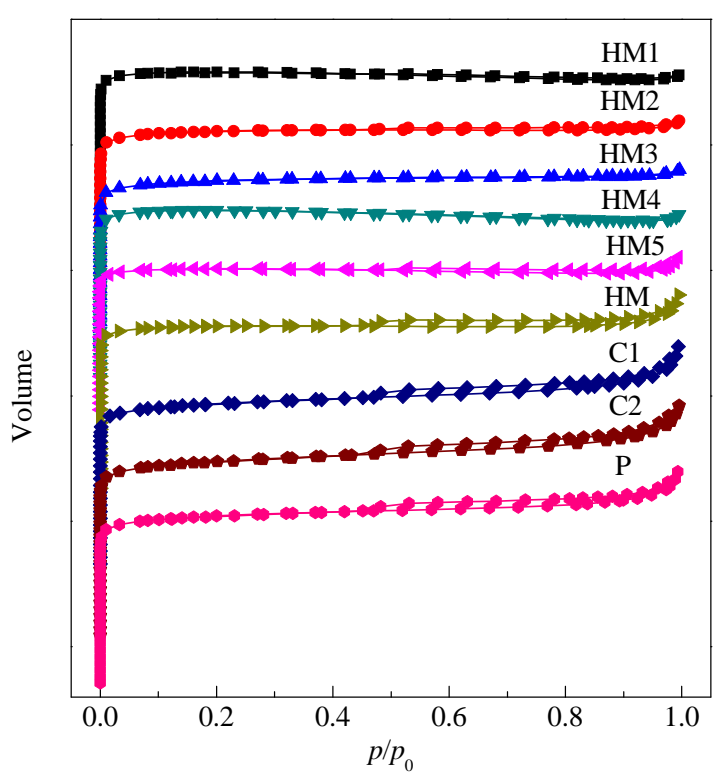

Fig. 2. Nitrogen adsorption isotherms of the H-MOR samples.

volumes were also little changed. This indicated that the change of the $\mathrm{Si} / \mathrm{Al}$ ratio in this range had little impact on the pore structure of MOR under the same synthesis conditions. HM5 synthesized with HMI as the template had the smallest BET surface area and micropore volume compared to the other samples. This was related to the weaker ability of HMI to direct the MOR structure, which was also supported by the XRD data [23]. All the samples after acidic treatment exhibited a larger surface area and mesopore volume than the parent HM sample. Meanwhile, the micropore surface area and volume decreased with acid leaching because of the slight collapse of the zeolitic structure caused by the removal of framework T-atoms. These results were in agreement with the conclusion obtained by the previous works on zeolite post-treatment $[24,25]$.

\subsection{Acidity characterization}

For reactions catalyzed by solid acids such as the carbonylation of DME, the quantity, strength and location of the acid sites are the most important factors that influence the catalytic properties. These are dependent on the content and distribution of $\mathrm{Al}$ in the zeolite. In previous studies, the steric confinement effect of MOR on DME carbonylation has been proposed and discussed [10]. So it is particularly important to quantitatively detect the acid sites located in the different channels of MOR. The micropore system of MOR possesses two pore channels: the larger pores consist of 12 -MR channels $(0.67 \mathrm{~nm} \times$ $0.70 \mathrm{~nm})$ and the smaller ones consist of 8-MR channels $(0.26$ $\mathrm{nm} \times 0.57 \mathrm{~nm}$ ), parallel to the direction of the 12-MR channels [18]. To investigate the nature of the acid sites in zeolites, several basic probe molecules with different sizes were employed, such as $\mathrm{NH}_{3}, \mathrm{~d}_{3}$-acetonitrile, trimethylamine and pyridine [2]. $\mathrm{NH}_{3}$ with a small kinetic diameter $(0.26 \mathrm{~nm})$ is extensively applied to determine the total amount of acid sites, especially in microporous zeolite, owing to its strong alkalinity and accessi- 
bility to the acid sites in the small channel. Pyridine is also widely used for monitoring acid sites because of its sensitivity in the IR spectrum. More importantly, it is easy to discriminate Brönsted and Lewis acid sites by their characteristic bands. In consideration of the MOR pore structure, pyridine (kinetic diameter, about $0.5 \mathrm{~nm}$ ) can probe the acid sites in the 12-MR channels, while the acid sites in the 8-MR channels are not accessible to pyridine. Here, we used both $\mathrm{NH}_{3}$-TPD and pyridine-adsorption IR to determine the acid properties of the MOR samples.

Figure 3 shows the $\mathrm{NH}_{3}$-TPD profiles of the MOR samples prepared with the different methods. One peak was at 500-550 $\mathrm{K}$ and the other at high temperature was broad and asymmetric. The curves were similar to those in the reported literature [26-29]. Until now, the interpretation of $\mathrm{NH}_{3}$-TPD of zeolites was not completely consistent. Generally speaking, the peak at low temperature was assigned to physically adsorbed or hydrogen-bonded $\mathrm{NH}_{3}$, while the acid sites gave rise to the peak at the higher temperature in zeolites. Some researchers have proposed that the higher asymmetric temperature peak be considered as a typical characteristic of Brönsted acid sites bonded to the framework $\mathrm{Al}$ atoms [28,30,31]. Niwa and coworkers [32] found good agreement between IR-TPD and MS-TPD of $\mathrm{NH}_{3}$ at the high temperature desorption, which suggested that the desorbed $\mathrm{NH}_{3}$ at the high temperature mainly came from $\mathrm{NH}_{4}+$ bonded on the Brönsted acid sites. Gounder's group [33] suggested that the center of the high temperature feature depended on the type of zeolites, which reflect the framework Brönsted acidity. In some other work, the $\mathrm{NH}_{3}$-TPD curve was deconvoluted into three peaks or even more peaks because of the existence of a shoulder peak along with the high temperature desorption peak [29,34,35]. Among these, the first peak or group was due to weakly adsorbed $\mathrm{NH}_{3}$, the middle one was normally attributed to Lewis acid sites with

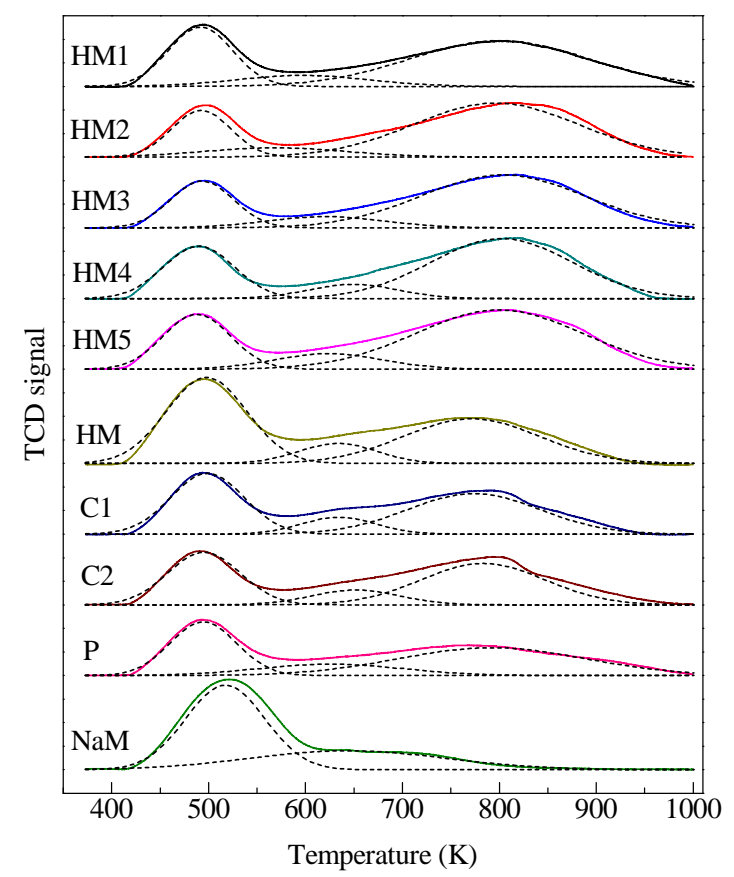

Fig. 3. $\mathrm{NH}_{3}-\mathrm{TPD}$ profiles of the MOR samples.
Table 2

Quantity of Brönsted acid sites in the different channels of MOR samples and catalytic performance.

\begin{tabular}{lccccc}
\hline Sample & $\begin{array}{c}B_{\text {framework }^{\mathrm{a}}} \\
(\mu \mathrm{mol} / \mathrm{g})\end{array}$ & $\begin{array}{c}B_{12-\mathrm{MR}}{ }^{\mathrm{b}} \\
(\mu \mathrm{mol} / \mathrm{g})\end{array}$ & $\begin{array}{c}B_{8-\mathrm{MR}} \\
(\mu \mathrm{mol} / \mathrm{g})\end{array}$ & $\begin{array}{c}B_{8-\mathrm{MR}} \\
(\%)\end{array}$ & $\begin{array}{c}\mathrm{STY}_{\mathrm{MA}} \\
\left(\mathrm{g} \mathrm{g}^{-1} \mathrm{~h}^{-1}\right)\end{array}$ \\
\hline HM1 & 1372 & 530 & 842 & 61.4 & 0.31 \\
HM2 & 1520 & 518 & 1002 & 65.9 & 0.36 \\
HM3 & 1451 & 491 & 960 & 66.2 & 0.35 \\
HM4 & 1425 & 486 & 939 & 65.9 & 0.33 \\
HM5 & 1662 & 454 & 1208 & 72.7 & 0.47 \\
HM & 1025 & 466 & 559 & 54.5 & 0.18 \\
C1 & 906 & 328 & 578 & 63.8 & 0.19 \\
C2 & 862 & 364 & 498 & 57.8 & 0.17 \\
P & 843 & 375 & 468 & 55.5 & 0.16 \\
NaM & n.d. & 24 & - & - & 0.01 \\
\hline
\end{tabular}

a Calculated based on the area of peak $\mathrm{P}_{3}$ in Fig. 3.

b Calculated based on Fig. 5.

a low thermal stability, and the one centered at the highest temperature correspond to the strong acid sites, which were referred to as framework Brönsted acid sites.

In our work, we also deconvoluted the $\mathrm{NH}_{3}$-TPD profiles into three peaks $\left(\mathrm{P}_{1}, \mathrm{P}_{2}\right.$, and $\left.\mathrm{P}_{3}\right)$. For the NaM sample, the peak at 800-850 K had completely disappeared and a low intensity and broad peak at $650 \mathrm{~K}$ was observed. From the results of the activity evaluation (Fig. 6 and Table 2), NaM was almost inactive. It is accepted that extra-framework $\mathrm{Al}$ species and cations compensated by the negative charge of the framework were the Lewis acid sites [36]. For DME carbonylation, Brönsted acid sites had been confirmed as the active centers [29]. Therefore, we attributed $\mathrm{P}_{2}$ and $\mathrm{P}_{3}$ to Lewis acid sites and framework Brönsted acid sites. Li's group [29] also analyzed the $\mathrm{NH}_{3}-\mathrm{TPD}$ profiles of MOR combined with the catalytic performance in DME carbonylation and came to a similar conclusion. They found that the area of the third peak was correlated to the activity, so they believed that $\mathrm{P}_{3}$ reflect the amount of framework Brönsted acid sites. Besides, ${ }^{27} \mathrm{Al}$ MAS NMR showed the existence of extra-framework $\mathrm{Al}$ species (signal near to $0 \mathrm{ppm}$, Fig. 4). Its proportion was from $11 \%-18 \%$ based on the integrated

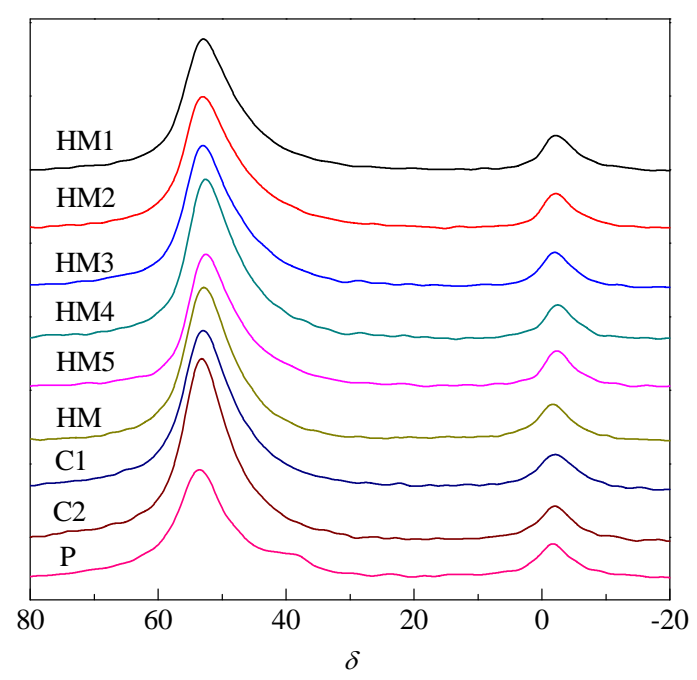

Fig. 4. ${ }^{27} \mathrm{Al}$ MAS NMR spectra of H-MOR prepared with different methods. 
area, which was in agreement with the ratio of the Lewis acid sites $(12 \%-24 \%)$ from the $\mathrm{NH}_{3}$-TPD peak fitting. From the analysis above, it is reasonable to calculate the total amount of the framework Brönsted acid sites from the area of $\mathrm{P}_{3}$. Compared to commercial HM and the post-treated samples, the as-synthesized samples showed a more intense and broader peak at high temperature, which was evidence of a larger number of Brönsted acid sites. The results of the quantitative analysis by peak fitting were summarized in Table 2. It was noteworthy that HM5 possessed the largest amount of Brönsted acid sites, although it had the highest $\mathrm{Si} / \mathrm{Al}$ ratio. This revealed the effect of HMI as the SDA in the synthesis of MOR.

Figure 5 presents the FTIR spectra of adsorbed pyridine in the range of $1400-1700 \mathrm{~cm}^{-1}$. As mentioned above, this illustrated the acidic property in the 12-MR from knowing the sizes of the pyridine molecule and the different pores in MOR. All the samples exhibited the characteristic bands assigned to pyridinium ions on Brönsted acid sites (1540 and $1630 \mathrm{~cm}^{-1}$ ) and pyridine molecules coordinated to Lewis acid sites (1450 and $1610 \mathrm{~cm}^{-1}$ ), respectively [37]. Moreover, the band at $1490 \mathrm{~cm}^{-1}$ was observed for all samples, which was attributed to the contribution of pyridine interacting with both Lewis and Brönsted acid sites [37]. More specifically, the band at $1454 \mathrm{~cm}^{-1}$ for the H-MOR samples (HM1-HM5, HM, C1, C2 and P) was due to the $\mathrm{C}-\mathrm{C}$ stretching vibration of the pyridine complex coordinated to unsaturated $\mathrm{Al}^{3+}$ ions [36]. A red shift occurred in the $\mathrm{NaM}$ sample because of the interaction between pyridine molecules and $\mathrm{Na}^{+}$ions [36]. When TEAOH was used as the SDA, the intensity of the bands at both 1540 and $1454 \mathrm{~cm}^{-1}$ slightly decreased with the decrease of $\mathrm{Al}$ content. These two bands of HM5 showed a weaker intensity, demonstrating less Brönsted acid sites and unsaturated $\mathrm{Al}^{3+}$ ions in the 12-MR. The acid-treated samples (C1, C2, and P) displayed less Brönsted acid sites and more Lewis acid sites than the parent HM sample, which could be ascribed to the removal of framework $\mathrm{Al}$ and the formation of unsaturated coordinated $\mathrm{Al}$ species through the post-treatment. The numbers of Brönsted acid sites in the 12-MR were calculated from Fig. 4 and listed in Table 2.

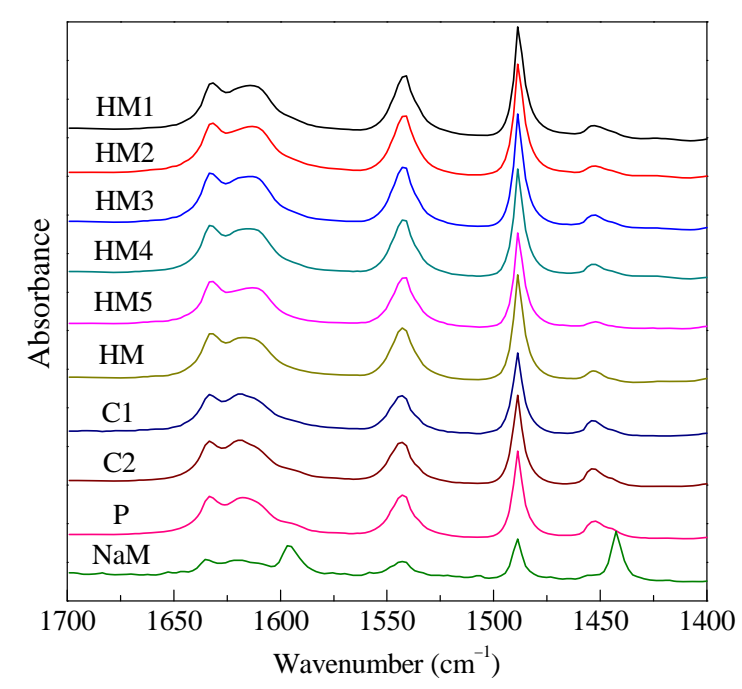

Fig. 5. FTIR spectra of adsorbed pyridine on the MOR samples.
Above, $\mathrm{NH}_{3}$-TPD was used to determine the total amount of framework Brönsted acid sites by peak deconvolution, while the quantity of Brönsted acid sites in the 12-MR channel was calculated from the area of the band at $1540 \mathrm{~cm}^{-1}$ in the IR spectrum. Therefore, we calculated the amount of Brönsted acid sites in the 8-MR (B8-MR) channels by Eq. (3). The results on the quantity of Brönsted acid sites in the different channels are listed in Table 2.

$$
B 8-\mathrm{MR}=B_{\text {framework }}-B_{12-\mathrm{MR}}
$$

As shown in Table 2, the variation of $B_{8 \text {-MR }}$ was similar to the

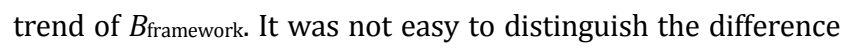
in the distribution of Brönsted acid sites in the MOR samples obtained by different methods. Thus, in order to provide a more intuitive understanding of the distribution of Brönsted acid sites in the different channels, we calculated the proportion of $B_{8-\mathrm{MR}}(\%)$ using Eq. (4).

$$
B_{8-\mathrm{MR}}=B_{8-\mathrm{MR}} / B_{\text {framework }} \times 100 \%
$$

The results revealed that the ratio of $B 8$-MR in all the samples ranged from $54.5 \%$ to $72.7 \%$. The commercial MOR had the least amount of $B$-Mr. Compared to the commercial sample and post-treated ones, the as-synthesized MOR exhibited a higher ratio of $B_{8-\mathrm{MR}}$, indicating the successful modification of $\mathrm{Al}$ distribution by controlling the synthesis conditions. In particular, HMI as the SDA remarkably increased the number of $B 8$-MR in terms of preferential location of $\mathrm{Al}$ atoms in the 8-MR channels of MOR. Jongkind et al. [18] offered an explanation for this result. Because HMI (kinetic diameter, $0.76 \mathrm{~nm}$ ) can only be accommodated in the 12-MR pores, the incorporation of $\mathrm{Al}$ in the larger pores would be blocked by the presence of the template. Hence, Al atoms were preferentially located in the smaller pores (8-MR). Treatment by citric acid or phosphoric acid was able to tune the distribution of the Brönsted acid sites. However, the dissolution of framework T-atoms inevitably occurred at the same time, resulting in the decrease of the total number of Brönsted acid sites. Therefore, increasing the ratio of $B_{8-\mathrm{MR}}$ could not neutralize the negative effects caused by the removal of framework $\mathrm{Al}$ species, which caused an ultimate reduction of B8-Mr.

\subsection{Catalytic performance for DME carbonylation}

The carbonylation of DME to MA was applied as a probe reaction to detect the variation of Brönsted acid sites. The initial catalytic performance are shown in Table 2 and Fig. 6 . The selectivity for MA over the different catalysts was above 95\%, reflecting the specificity of the 8-MR channels of MOR [14]. Acid treatment (sample C1, C2, and P) led to a slight decrease of selectivity owing to the deterioration of the framework structure. This can be deduced by the increase of the surface area and mesopore volume, and the decrease of relative crystallinity. The results showed almost undetectable MA from the NaM sample and varying amounts from H-MOR from 0.16 to 0.47 $\mathrm{g} \mathrm{g}^{-1} \mathrm{~h}^{-1}$, which proved that the replacement of $\mathrm{Na}^{+}$cations by hydrogen protons generated active sites for MA formation. For the H-MOR samples synthesized with TEAOH as the template, the conversion of DME increased first and then decreased with increasing $\mathrm{Si} / \mathrm{Al}$ ratio. When HMI was used as a template, a 


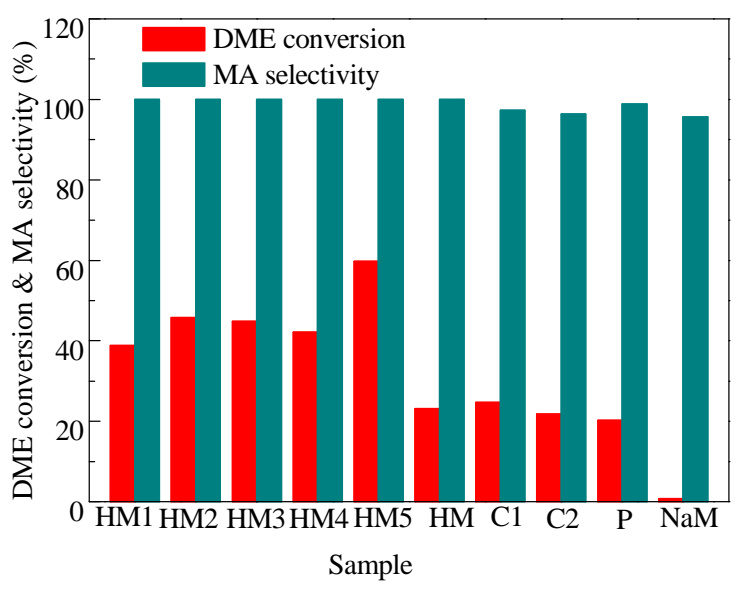

Fig. 6. Conversion of DME and selectivity for MA over MOR prepared with different methods. Reaction condition: $\mathrm{DME} / \mathrm{CO}=1 / 49,473 \mathrm{~K}, 1.5$ MPa, $6000 \mathrm{~h}^{-1}$.

maximum conversion with similar selectivity was obtained even at low Al content, poorer crystallinity and smaller surface area. The yield was up to $0.47 \mathrm{~g} \mathrm{~g}^{-1} \mathrm{~h}^{-1}$. By considering the results of acidity characterization, the good catalytic performance was attributed to the concentration of framework $\mathrm{Al}$ atoms in the 8-MR pores. Even under mild conditions by using a weak acid solution with a low concentration, acid treatment decreased the activity of the catalyst due to Al leaching of the zeolite framework.

Figure 7 shows the STY of MA as a function of the number of $B$ 8-MR for the different samples. MA formation increased in parallel with the amount of Brönsted acid sites in the 8-MR channels. Liu's group [38] confirmed that the carbonylation reaction only occurred on the acid sites in the 8-MR side pockets by in situ diffuse reflectance infrared Fourier transform spectroscopy (DRIFTS). Iglesia's group [14] have reported a similar result in their work previously; $\mathrm{Na}^{+}$and $\mathrm{Co}^{2+}$ cation exchange were used to reduce the acid sites in the different channels. In a further study, an aqueous solution of oxalic acid was used to discern the effect of Al content on the carbonylation of DME [15]. However, all these conclusions were obtained from the same parent H-MOR and post-treated samples. In this study, synthesis as well as chemical post-treatment was used for modifying

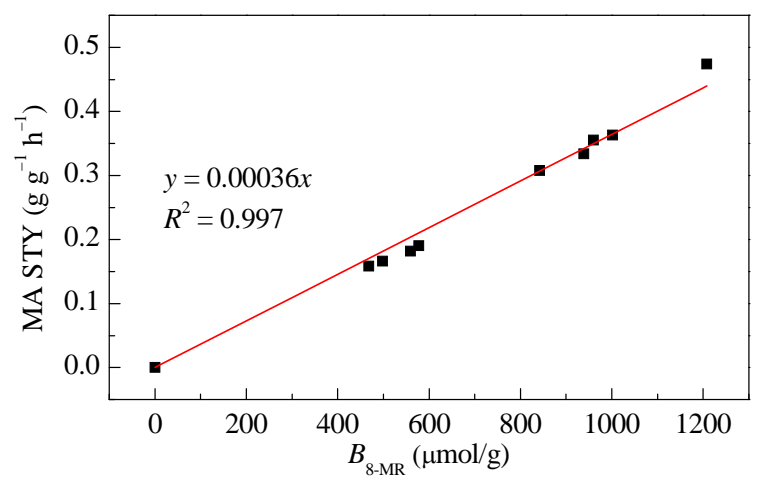

Fig. 7. Correlation between the reactivity of DME carbonylation and amount of Brönsted acid sites in 8-MR channels. the amount and distribution of the Brönsted acid sites. Compared with the previous post-treatment approaches, synthetic control is a more effective strategy to promote the carbonlyation of DME. Up to now, some synthesis methods were applied to improve the catalytic activity of MOR for DME carbonylation. Shen's group [39] found an excellent activity over nanosized H-MOR, which was synthesized using $N, N, N, N^{\prime}, N^{\prime}, N^{\prime}$ hexaethylpentanediammonium cation as the template. They ascribed the significant improvement to a facilitated diffusion process. Liu's group [40] also reported enhanced activity on nanocrystal-assembled hierarchical MOR zeolites because of the shortened diffusion path. Li's group [29] fabricated nanosheet-assembled H-MOR without an organic template. The unique structure gave a larger amount of the framework Brönsted acidic sites, which resulted in higher activity and also better stability. Here, we found that the Brönsted acid sites in MOR can be tailored by controlling the composition of the sol-gel or using an appropriate SDA. In particular, a much higher proportion of $B_{8-\mathrm{MR}}$ was obtained when HMI was used as the SDA. The higher rates of DME carbonylation verified the successful modification of the acid sites distribution in MOR.

\section{Conclusions}

We successfully regulated the acid properties of MOR by different methods. The quantity of Brönsted acid sites and also their distribution were modified through both synthesis and post-treatment methods. Controllable synthesis is a promising approach to synthesize H-MOR zeolite with a high concentration of Brönsted acid sites. The composition of $\mathrm{Si}$ and $\mathrm{Al}$ in the sol-gel influenced the distribution of Brönsted acid sites. More importantly, HMI as the SDA gave an enrichment of Brönsted acid sites in the 8-MR channels even at a low Al content in zeolite framework. The rate of MA formation from DME carbonylation, which is a typical spatially confined reaction in MOR, exhibited a linear dependence on the amount of Brönsted acid sites located in the 8-MR. This confirmed that the regulation of the Brönsted acid site distribution and location in MOR was achieved. Our results provide a better understanding of the catalytic site requirement in zeolites. Rational design of the spatial constraints around active sites in inorganic structures is a promising strategy to develop an efficient catalyst with excellent activity and selectivity.

\section{References}

[1] A. Ghorbanpour, A. Gumidyala, L. C. Grabow, S. P. Crossley, J. D. Rimer, ACS Nano, 2015, 9, 4006-4016.

[2] S. Y. Huang, Y. Wang, Z. Z. Wang, B. Yan, S. P. Wang, J. L. Gong, X. B. Ma, Appl. Catal. A, 2012, 417-418, 236-242.

[3] T. Yokoi, H. Mochizuki, S. Namba, J. N. Kondo, T. Tatsumi, J. Phys. Chem. C, 2015, 119, 15303-15315.

[4] A. Vjunov, J. L. Fulton, T. Huthwelker, S. Pin, D. H. Mei, G. K. Schenter, N. Govind, D. M. Camaioni, J. Z. Hu, J. A. Lercher, J. Am. Chem. Soc., 2014, 136, 8296-8306.

[5] A. Janda, A. T. Bell, J. Am. Chem. Soc., 2013, 135, 19193-19207.

[6] Y. Roman-Leshkov, M. Moliner, M. E. Davis, J. Phys. Chem. C, 2011, $115,1096-1102$ 


\title{
Graphical Abstract
}

Chin. J. Catal., 2016, 37: 1530-1538 doi: 10.1016/S1872-2067(16)62484-1

Modifying the acidity of H-MOR and its catalytic carbonylation of dimethyl ether

Meixia Wang, Shouying Huang *, Jing Lü, Zaizhe Cheng, Ying Li, Shengping Wang, Xinbin Ma*

Tianjin University; Collaborative Innovation Center of Chemical Science and Engineering (Tianjin)

Using hydrothermal synthesis that favored a higher proportion of Brönsted acid sites in the 8-membered ring channel gave a higher yield of methyl acetate from dimethyl ether carbonylation.

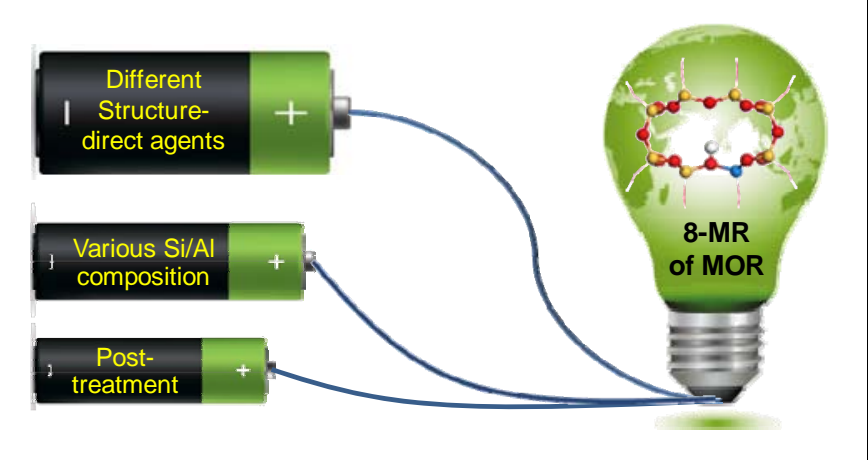

[7] A. B. Pinar, C. Márquez-Álvarez, M. Grande-Casas, J. Pérez- Pariente, J. Catal., 2009, 263, 258-265.

[8] J. Dědeček, Z. Sobalík, B. Wichterlová, Catal. Rev. Sci. Eng., 2012, 54, 135-223.

[9] P. Cheung, A. Bhan, G. J. Sunley, E. Iglesia, Angew. Chem. Int. Ed., 2006, 45, 1617-1620.

[10] A. Bhan, E. Iglesia, Acc. Chem. Res., 2008, 41, 559-567.

[11] M. Boronat, C. Martínez-Sánchez, D. Law, A. Corma, J. Am. Chem. Soc., 2008, 130, 16316-16323.

[12] J. L. Liu, H. F. Xue, X. M. Huang, Y. Li, W. J. Shen, Catal. Lett., 2010, $139,33-37$.

[13] X. G. Li, X. G. San, Y. Zhang, T. Ichii, M. Meng, Y. S. Tan, N. Tsubaki, ChemSusChem, 2010, 3, 1192-1199.

[14] A. Bhan, A. D. Allian, G. J. Sunley, D. J. Law, E. Iglesia, J. Am. Chem. Soc., 2007, 129, 4919-4924.

[15] P. Cheung, A. Bhan, G. J. Sunley, D. J. Law, E. Iglesia, J. Catal., 2007, $245,110-123$.

[16] A. L. Lv, H. Xu, H. H. Wu, Y. M. Liu, P. Wu, Microporous Mesoporous Mater., 2011, 145, 80-86.

[17] C. A. Emeis, J. Catal., 1993, 141, 347-354.

[18] H. Jongkind, K. P. Datema, S. Nabuurs, A. Seive, W. H. J. Stork, Microporous Mater., 1997, 10, 149-161.

[19] B. W. Lu, T. Tsuda, H. Sasaki, Y. Oumi, K. Itabashi, T. Teranishi, T. Sano, Chem. Mater., 2004, 16, 286-291.

[20] H. J. Zhang, Y. M. Liu, Z. Jiao, M. Y. He, P. Wu, Ind. Eng. Chem. Res., 2009, 48, 4334-4339.

[21] G. Y. Bai, Z. Ma, L. J. Shi, X. W. Lan, Y. L. Wang, J. Han, M. D. Qiu, H. L. Fu, P. D. Liu, Appl. Catal. A, 2012, 427-428, 114-118.

[22] M. Derewinski, P. Sarv, X. Y. Sun, S. Müller, A. C. van Veen, J. A. Lercher, J. Phys. Chem. C, 2014, 118, 6122-6131.

[23] P. Sharma, P. Rajaram, R. Tomar, J. Colloid Interf. Sci., 2008, 325, 547-557.

[24] Y. J. Jin, C. C. Xiao, J. H. Liu, S. D. Zhang, S. Asaoka, S. L. Zhao, Microporous Mesoporous Mater., 2015, 218, 180-191.

[25] S. Y. Huang, P. Z. Chen, B. Yan, S. P. Wang, Y. L. Shen, X. B. Ma, Ind. Eng. Chem. Res., 2013, 52, 6349-6356.

[26] A. Sultana, M. Haneda, T. Fujitani, H. Hamada, Microporous Mesoporous Mater., 2008, 111, 488-492.

[27] M. Niwa, N. Katada, Catal. Surv. Jpn., 1997, 1, 215-226.

[28] F. Lónyi, J. Valyon, Microporous Mesoporous Mater., 2001, 47, 293-301.

[29] Y. H. Liu, N. Zhao, H. Xian, Q. P. Cheng, Y. S. Tan, N. Tsubaki, X. G. Li, ACS Appl. Mater. Interf., 2015, 7, 8398-8403.

[30] G. L. Woolery, G. H. Kuehl, H. C. Timken, A. W. Chester, J. C. Vartuli, Zeolites, 1997, 19, 288-296.

[31] H. F. Xue, X. M. Huang, E. S. Zhan, M. Ma, W. J. Shen, Catal. Commun., 2013, 37, 75-79.

[32] K. Suzuki, T. Noda, N. Katada, M. Niwa, J. Catal., 2007, 250 $151-160$

[33] S. A. Bates, W. N. Delgass, F. H. Ribeiro, J. T. Miller, R. Gounder, J. Catal., 2014, 312, 26-36.

[34] Z. Liu, Z. D. Zhang, W. Xing, S. Komarneni, Z. F. Yan, X. H. Gao, X. P. Zhou, Nanoscale Res. Lett., 2014, 9, 550.

[35] L. Wang, W. Li, S. J. Schmieg, D. Weng, J. Catal., 2015, 324, 98-106.

[36] Y. Y. Dong, S. Y. Huang, S. P. Wang, Y. J. Zhao, J. L. Gong, X. B. Ma, ChemCatChem, 2013, 5, 2174-2177.

[37] H. M. Zhan, S. Y. Huang, Y. Li, J. Lü, S. P. Wang, X. B. Ma, Catal. Sci. Technol., 2015, 5, 4378-4389.

[38] H. Zhou, W. L. Zhu, L. Shi, H. C. Liu, S. P. Liu, Y. M. Ni, Y. Liu, Y. L. He, S. L. Xu, L. N. Li, Z. M. Liu. J. Mol. Catal. A, 2016, 417, 1-9.

[39] H. F. Xue, X. M. Huang, E. Ditzel, E. S. Zhan, M. Ma, W. J. Shen, Ind. Eng. Chem. Res., 2013, 52, 11510-11515.

[40] Y. Y. Yuan, L. Y. Wang, H. C. Liu, P. Tian, M. Yang, S. T. Xu, Z. M. Liu, Chin. J. Catal., 2015, 36, 1910-1919.

\section{丝光沸石的酸性质调控及在二甲醚羰基化反应中的催化性能}

\author{
王美霞, 黄守莹*, 吕 静, 程载哲, 李 媖, 王胜平, 马新宾 \\ 天津大学化工学院绿色合成与转化教育部重点实验室; 天津化学化工协同创新中心, 天津 300072
}

摘要: 二甲醚 (DME) 羰基化制乙酸甲酯 (MA) 及 MA 加氢制乙醇, 是一条新兴的合成气间接法制乙醇工艺. 其中, DME 羰基化合成 MA 反应原子经济性高, 反应条件温和. 特别是以丝光沸石 (MOR) 为催化剂时, 反应在较低温度 (473 K) 下 MA 选择性即可达到 99\%, 这使得该工艺具有良好的竞争力和工业化前景. 在已有的文献报道中, 学者们将 MA 的高选择 性归结于分子笁八元环 (8-MR) 结构的限域效应, 红外和 DFT 计算表明八元环的 Brönsted 酸位上可以专一性催化 CO 插 
入吸附态的甲基形成乙酰基中间体. 为了建立八元环 Brönsted 酸位点与活性的关系, 研究者一般采用化学脱铝和离子交 换等方法减少八元环 Brönsted 酸位点, 以观察反应活性降低的趋势. 事实上, 采用直接合成手段选择性地调控 H-MOR 的 酸性, 以此提高其羰基化活性的研究报道十分有限. 因此, 我们通过多种方法来调变 MOR 的骨架 $\mathrm{Al}$ 元素分布, 包括改变 水热合成中溶胶的组成、选择适宜的模板剂以及对样品进行酸处理等, 获得了一系列酸量和酸分布不同的 H-MOR 分子篮. 通过考察 DME 羰基化制 MA 的反应性能, 进一步明确酸性调控对分子篮催化剂结构和性能的影响.

首先通过 XRD 和 $\mathrm{N}_{2}$ 物理吸附对所有样品的织构性质进行表征, 结果发现各样品均为纯的 MOR 晶相, 相对结晶度也 较为相近. 比表面积和孔分布计算结果显示, 各样品的孔结构也大致相同. 特殊地, 以环己亚胺 (HMI) 为模板时得到的样 品结晶度较低, 比表面积和孔体积较小. 这是因为 HMI 的碱性较弱, 因此在水热合成过程中的结构导向力较弱, 无法高效 地促进分子篮成核. 酸处理会造成分子篮骨架 $\mathrm{T}$ 原子少量脱除, 导致结构轻微破坏, 但总的来说影响不大.

在排除了晶相与结构方面的差异后, 我们基于不同环内酸性位点对不同尺寸碱性分子的可接近性存在差异这一特点, 结合 ICP-OES, ${ }^{27} \mathrm{Al}$ MAS NMR, $\mathrm{NH}_{3}$-TPD 和 Py-FTIR 等多种表征方法对 MOR 分子篎八元环和十二元环的 Brönsted 酸位 进行定量分析. 通过计算骨架 $\mathrm{Al}$ 含量及 $\mathrm{NaM}$ 样品的对照, 验证了 $\mathrm{NH}_{3}$ - TPD 的峰位归属, 认定高温处的 $\mathrm{NH}_{3}$ 脱附峰能够 准确反映 H-MOR 骨架中 Brönsted 的酸总量. 通过 Py-FTIR 获得了 H-MOR 样品中十二元环的 Brönsted 酸量. 由此发现 通过不同方法得到的 H-MOR 催化剂上八元环内的 Brönsted 酸比例存在较大差异 (55.5\%-72.7\%), 并且普遍高于商业 H-MOR 样品 (54.5\%), 说明我们通过控制合成条件或者酸处理可以有效地调控骨架 $\mathrm{Al}$ 元素的分布, 进而导致 Brönsted 酸 在不同环内的分布比例发生变化. 尤其是当 HMI 作模板剂时, 由于其分子尺寸较大, 仅可以进入分子篮的十二元环, 促使 $\mathrm{Al}$ 原子向八元环富集, 因而在样品结晶度较低的情况下, 八元环内的 Brönsted 酸仍显著增加.

反应测试结果表明, 不同催化剂虽然均具有较高的选择性, 但反应初始活性差别明显. 将 MA 的生成速率与八元环的 Brönsted 酸量相关联, 发现二者呈线性正相关关系, 由此验证了文献中八元环内 Brönsted 酸位是 DME 羰基化制 MA 反应 的活性位点这一学术观点, 同时更加肯定了我们对分子篮酸性的调控是有效且成功的. 我们的实验结果为分子篮的酸量 和酸分布调控提供了有益信息, 也为后期 DME 羰基化反应催化剂的优化和设计提供了参考.

关键词: 沸石; 丝光沸石; 酸性质调控; 水热合成; 结构导向剂; 后处理; 二甲醚羰基化

收稿日期: 2016-04-13. 接受日期: 2016-05-30. 出版日期: 2016-09-05.

*通讯联系人. 电话: (022)27409880; 传真: (022)87401818; 电子信箱: huangsy@tju.edu.cn

\#通讯联系人. 电话: (022)27409880; 传真: (022)87401818; 电子信箱: xbma@tju.edu.cn

基金来源：国家自然科学基金 (21325626, 21406120); 中国博士后科学基金 (2014M560181, 2015T80214).

本文的英文电子版由Elsevier出版社在ScienceDirect上出版(http://www.sciencedirect.com/science/journal/18722067). 